\title{
IMAM AL-GHAZALI: PEMIKIRAN HUKUM EKONOMI ISLAM ABAD KE 5 H/ 11 M
}

\author{
Hamdan Firmansyah \\ S-2 Hukum Ekonomi Syariah UIN Sunan Gunumg Djati Bandung \\ Email: abihilqi@gmail.com
}

\begin{abstract}
ABSTRAK
Pada tahun 1070 M Corpus Iuris Civilis atau "Kitab Undang-Undang Yustinianus", ditemukan kembali di Italia Utara di kawasan barat Eropa, sebagian besar dari kerajaan yang ada melembagakan segelintir pranata Romawi yang tersisa. Perang Salib, yang mula-mula diserukan pada 1095, adalah upaya militer umat Kristen Eropa Barat untuk merebut kembali kekuasaan atas Tanah Suci dari umat Muslim. Perkembangan Islam mengalami fase kemajuan pada tahun 650 -1250 M yang ditandai dengan sangat luasnya kekuasaan Islam, ilmu dan sain mengalami kemajuan dan penyatuan antar wilayah Islam. Tahun $1058 \mathrm{M}$ lahir tokoh besar Islam Imam al-Ghazali bernama lengkap Abu Hamid Muhammad bin Muhammad al-Tusi al-Ghazali. Beliau telah berjasa dalam perkembangan pemikiran ekonomi Islam. Bahkan pemikirannya dimanfaatkan oleh pemikir sesudahnya di dunia Islam dan non Islam.

Kata kunci: Pranata, hukum ekonomi syariah, Imam al-Ghazali
\end{abstract}

\begin{abstract}
In $1070 \mathrm{M}$ Corpus Iuris Civilis, or "Book of Justinian", was rediscovered in northern Italy in the western region of Europe, most of the existing kingdom instituted a handful of remaining Roman institutions. The Crusade, which was first called for in 1095, is a military effort of Western European Christians to regain power over the Holy Land from Muslims. The development of Islam experienced a phase of progress in the year $650-1250 \mathrm{M}$ which was marked by the very wide power of Islam, science and science experienced progress and unification between Islamic territories. In 1058, the great Islamic leader Imam al-Ghazali was born full name Abu Hamid Muhammad bin Muhammad al-Tusi al-Ghazali. He has contributed to the development of Islamic economic thought. Even his thoughts were utilized by thinkers afterwards in the world of Islam and non-Islam.
\end{abstract}

Keywords: pranata, sharia economic law, imam al-Ghazali.

\section{Pendahuluan}

Selepas tahun $1000 \mathrm{M}$, populasi eropa mengalami peningkatan besar-besaran berkat munculnya inovasi-inovasi di bidang teknologi dan pertanian. Ada dua cara menata masyarakat pada puncak abad pertengahan, yakni manorialisme dan feodalisme. ${ }^{1}$ Pada tahun 1070 M Corpus Iuris Civilis ${ }^{2}$ atau "Kitab Undang-Undang

\footnotetext{
${ }^{1}$ Manorialisme adalah pengaturan rakyat jelata menjadi pemukim di desa-desa, dengan kewajiban membayar sewa lahan dan bekerja bakti bagi kaum bangsawan, sementara feodalisme adalah
} 


\section{Tahkím}

Vol. XIV, No. 1, Juni 2018

Yustinianus," ditemukan kembali di Italia Utara di kawasan barat eropa, sebagian besar dari kerajaan yang ada melembagakan segelintir pranata Romawi yang tersisa. Perang Salib, yang mula-mula diserukan pada 1095, adalah upaya militer umat Kristen Eropa Barat untuk merebut kembali kekuasaan atas Tanah Suci dari umat Muslim. Kehidupan intelektual ditandai oleh skolastisisme, filsafat yang mengutamakan keselarasan antara iman dan akal budi, dan ditandai pula oleh pendirian universitas-universitas. Teologi Thomas Aquinas, lukisan-lukisan Giotto, puisi-puisi Dante dan Chaucer, perjalananperjalanan Marco Polo, dan katedral-katedral bergaya arsitektur Gotik semisal Katedral Chartres, adalah beberapa dari capaian-capaian puncak abad pertengahan.

Perkembangan Islam mengalami fase kemajuan pada tahun 650-1250 M yang ditandai dengan sangat luasnya kekuasaan Islam, ilmu dan sain mengalami kemajuan dan penyatuan antar wilayah Islam. Tidak mengherankan pengaruh Islam sampai ke Indonesia menjelang abad ke 11 hingga abad ke 13, masyarakat muslim sudah ada di Samudera Pasai, Pelak, dan Palembang di Sumatera. Di Jawa terdapat makam Fatimah binti Maimun di Leran Gresik yang berangka tahun $475 \mathrm{H}$ atau $1082 \mathrm{M}$, dan terdapat makam-makam Islam di Tralaya yang berasal dari abad ke 13. Sudah tentu adanya orang muslim ini sangat erat hubungannya dengan perdagangan. Inskripsi pada batu nisan Fatimah Binti Maimun dianggap sebagai inskripsi Islam yang tertua di Indonesia, sekaligus sumber asli tertulis yang tertua tentang kehadiran Islam di Kepulauan Nusantara. $^{3}$

\section{Pemikiran Ekonomi al-Ghazali}

\section{A. Riwayat Hidup Al-Ghazali}

Imam al-Ghazali bernama lengkap Abu Hamid Muhammad bin Muhammad alTusi al-Ghazali ${ }^{4}$ lahir di Tus, sebuah kota kecil di khurasan, iran, pada tahun $450 \mathrm{H}$ $(1058 \mathrm{M}) .^{5}$ Sejak kecil, imam al-Ghazali hidup dalam dunia tasawuf. Pertama-tama Imam al-Ghazali belajar bahasa arab dan fiqih di kota Tus, kemudian pergi ke kota jurjan untuk belajar dasar-dasar ushul fiqih. Setelah kembali ke kota tus selama beberapa waktu, ia pergi ke Naisabur untuk melanjutkan rihlah ilmiahnya. Al-Ghazali belajar kepada Al-Haramain Abu Al-Maah Al-Juwaini. ${ }^{6}$

Setelah itu ia berkunjung ke kota Baghdad, ibu kota Daulah Abasiyah, dan bertemu Wadzir Nidzham Al-Mulk. Al-Ghazali mendapat penghormatan dan

\footnotetext{
struktur politik yang mewajibkan para kesatria dan bangsawan-bangsawan kelas bawah untuk maju berperang membela majikan mereka sebagai ganti anugerah hak atas sewa lahan.

${ }^{2}$ Kitab undang-undang Kekaisaran Bizantium

${ }^{3}$ Kalus Guilot, Inskripsi Islam Tertua di Indonesia, (Jakarta: KPG, 2008), h. 11

${ }^{4}$ Yadi Janwari, Pemikiran Ekonomi Islam, (Bandung: PT Remaja Rosdakarya, 2016), h. 184

${ }^{5}$ Euis Amalia, Sejarah Pemikiran Ekonomi Islam, (Depok: Gramata Publiishing, 2010), h 163

${ }^{6}$ Adiwarman A. Karim, Sejarah Pemikiran Ekonomi Islam, (Jakarta: Raja Grafindo Persada,
} 2006), h. 314 


\section{Tahbím}

Vol. XIV, No. 1, Juni 2018

penghargaan. Pada tahun $483 \mathrm{H}(1090 \mathrm{M})$, diangkat menjadi guru di madrasah Nizhamiyah. Pada tahun 488H/1095M imam Ghazali meninggalkan Baghdad dan pergi menuju Syiria. Kemudian pindah ke palestina. Setelah menunaikan ibadah haji dan menetap beberapa waktu di kota Iskandariah, Mesir. Al-Ghazali kembali ke kota Tus pada tahun $499 \mathrm{H}$, imam al-Ghazali wafat pada tanggal 14 jumadil akhir $505 \mathrm{H}$ atau 19 Desember $1111 \mathrm{M}$.

\section{B. Karya-karya dan Pemikiran Ekonomi Imam Al-Ghazali}

Karya Imam al-Ghazali diperkirakan telah menghasilkan 300 buah karya tulis $^{7}$ yang meliputi berbagai disiplin ilmu. Namun demikian, yang ada hingga ini hanya 84 buah diantaranya Ihya 'Ulum al-Din, al-Munqidz min al-Dhalal, Tahaful al-Falasifah, Minhaj al-Abidin, Qawa'id al-'Aqaid, al-Mustashfa min 'Ilm al-Ushul, Mizan al'Amal, misykat al-Anwar, Kimia al-Sa'adah, al- Wajiz, Syifa al-Ghalil, dan al-Tibr alMasbuk fi Nasihat al-Mulk.

Sebagaimana halnya para cendekiawan muslim terdahulu, perhatian al-Ghazali terhadap kehidupan masyarakat tidak terfokus pada satu bidang tertentu, tetapi meliputi seluruh aspek kehidupan manusia. Pemikiran al-Ghazali didasarkan pada pendekatan tasawuf. Corak pemikiran ekonominya dituangkan dalam kitab Ihya 'Ulum al-Din, alMustashfa, Mizan Al-'Amal, dan Al-Tibr al Masbu fi Nasihat al-Muluk. Dengan memperhatikan para perilaku individu yang dibahasnya menurut prespektif al-Qur'an, sunnah, dan fatwa sahabat tabi'in serta petuah-petuah para sufi terkemuka.

Menurut mustafa Anas Zarqa, al-Ghazali merupakan cendekiawan muslim yang pertama yang merumuskan konsep fungsi kesejahteraan (maslahah) sosial yang pertama. Pemikiran sosio ekonomi al-Ghazali berakal dari sebuah konsep yang dia sebut sebagai "Fungsi Kesejahteraan Sosial Islami”. Menurut al-Ghazali kesejahteraan dari semua masyarakat tergantung pada pencarian dan pemeliharaan lima tujuan dasar atau muqashid assyariah. Ia menitikberatkan bahwa sesuai tuntunan wahyu, tujuan utama kehidupan umat manusia adalah untuk mencapai kebaikan didunia dan akhirat. ${ }^{8}$

Al-Ghazali mendefinisikan aspek ekonomi dari fungsi kesejahteraan sosialnya dalam sebuah kerangka hierarki utilitas individu dan sosial yang tri partie yakni daruriat, hajiyat dan tahsiniyat. ${ }^{9}$ Hierarki tersebut merupakan sebuah klasifikasi peninggalan tradisi Aristotelian yang disebut sebagai kebutuhan oridinal yang terdiri

\footnotetext{
${ }^{7}$ Yadi Janwari, op.cit., h. 185

${ }^{8}$ Abu Hamid Al Ghazali, Ihya 'Ulum al-Din, Juz 2, (Beirut : Dar al-Nadwah,t.th.), h. 109

${ }^{9}$ Misbahul Munir, Ajaran-Ajaran Ekonomi Rasulullah Kajian Hadits Nabi dalam Perspektif Ekonomi, (Jakarta: UIN-Press, 2007), h. 17-18
} 


\section{Tahkím}

Vol. XIV, No. 1, Juni 2018

dari kebutuhan dasar, kebutuhan terhadap barang-barang eksternal dan kebutuhan terhadap barang-barang psikis. ${ }^{10}$

Mayoritas pembahasan al-Ghazali mengenai berbagai permasalahan ekonomi terdapat dalam kitab Ihya 'Ulum al-Din. Beberapa tema ekonomi yang dapat diangkat dari pemikiran al-Ghazali diantaranya mencakup pertukaran sukarela dan evolusi pasar, aktinitas produksi, barter dan evolusi uang, serta peran negara dan keuangan publik.

\section{Aspek-aspek Hukum dalam Pemikiran Al-Mawardi dan Al-Ghazali}

\section{A. Al-Mawardi}

\section{Negara dan Aktivitas Ekonomi}

Teori keuangan publik selalu terkait dengan peran negara dalam kehidupan ekonomi, yang sangat berperan untuk memenuhi kebutuhan kolektif seluruh warga negaranya. al-Mawardi berpendapat bahwa pelaksanaan Imamah (kepemimpinan politik keagamaan) merupakan kekuasaan mutlak (absolut) dan pembentukanya merupakan suatu keharusan demi terpeliharanya agama dan pengelolaan dunia. ${ }^{11}$

Dalam perspektif ekonomi, pernytaan al-Mawardi ini berarti bahwa negara memiliki peran aktif demi trealisasinya tujuan material dan sepiritual. Yang menjadi kewajiban moral bagi bangsa dalam membantu merealisasikan kebaikan bersama, yaitu memelihara kepentingan masyarakat serta mempertahankan stabilitas dan pertumbuhan ekonomi. ${ }^{12}$ Selanjutnya al-mawardi berpendapat bahwa negara harus menyediakan infrastruktur yang diperlukan bagi perkembangan ekonomi dan kesejahteraan umum. Menurutnya, "jika hidup dikota menjadi tidak mungkin karena tidak berfungsinya fasilitas sumber air minum, atau rusaknya tembok kota, maka Negara harus bertanggung jawab untuk memperbaikinya dan jika tidak memiliki dana, negara harus menemukan jalan untuk memperolehnya." Dalam mengadakan proyek dalam kerangka pemenuhan kepentingan umum, Negara dapat menggunakan dana Baitul Mal atau membebankan kepada individu-individu yang memiliki sumber keuangan yang memadai.

Tugas-tugas negara dalam pemenuhan kebutuhan dasar setiap warga negara adalah melindungi agama, menegakkan hukum dan stabilitas, memelihara batas negara Islam, menyediakan iklim ekonomi yang kondusif, menyediakan administrasi publik, peradilan, dan pelaksanaan hukum Islam, mengumpulkan pendapat dari berbagai sumber yang tersedia serta menaikannya dengan menerapkan pajak baru jika situasi

\footnotetext{
${ }^{10}$ ToddLowry, The Archeology of Economic Ideas: The Classied Greek Tradition, (Durham: Duke University Press, 1987), h. 220

${ }^{11}$ Al-Mawardi, Al-Ahkam as-Sulthaniyyah, (Bairut: Dar al-Kutub, 1978), h. 5.

${ }^{12}$ Ibid., h. 15-16.
} 


\section{Tahkím}

Vol. XIV, No. 1, Juni 2018

menuntutnya dan membelanjakan dana Baitul Mal untuk berbagai tujuan yang telah menjadi kewajibanya.

\section{a. Perpajakan}

Sebagaimana trend pada masa klasik, masalah perpajakan juga tidak luput dari perhatian al-Mawardi. Menurutnya penilaian atas kharaj harus bervariasi sesuai dengan faktor-faktor yang menentukan kemampuan tanah dalam membayar pajak, yaitu kesuburan tanah, jenis tanaman dan sistem irigasi. Di samping ketiga faktor tersebut, al-Mawardi juga mengungkapkan faktor yang lain, yaitu jarak antara tanah yang menjadi objek kharaj dengan pasar.

Dengan demikian, dalam pandangan Al-Mawardi, keadilan baru akan terwujud terhadap para pembayar pajak jika para petugas pemungut pajak mempertimbangkan setidaknya empat faktor dalam melakukan penilaian suatu objek kharaj. Tentang metode penetapan kharaj, al-Mawardi menyarankan untuk menggunakan salah satu dari tiga metode yang pernah diterapkan dalam sejarah Islam, yaitu: (1) Metode Misahah, yaitu metode penetapan kharaj berdasarkan ukuran tanah (2) Metode penetapan kharaj berdasarkan ukuran tanah yang ditanami saja (3) Metode Musaqah, yaitu metode penetapan kharaj berdasarkan persentase dari hasil produksi.

\section{b. Baitul Mal}

Seperti yang telah dikemukakan, al-Mawardi menyatakan bahwa untuk membiayai belanja negara dalam rangka memenuhi kebutuhan dasar setiap warganya, negara membutuhkan lembaga keuangan negara (Baitul Mal) yang didirikan secara permanen. Melalui lembaga ini, pendapatan negara dari berbagai sumber akan disimpan dalam pos yang terpisah dan dibelanjakan sesuai dengan alokasinya masingmasing.

Lebih jauh, al-Mawardi menegaskan, Baitul Mal bertanggungjawab untuk memenuhi kebutuhan publik. Ia mengklasifikasikan berbagai tanggung jawab Baitul Mal ke dalam dua hal, yaitu tanggung jawab yang timbul dari berbagai harta benda yang disimpan di Baitul Mal sebagai amanah untuk didistribusikan kepada mereka yang berhak dan tanggung jawab yang timbul seiring dengan adanya pendapatan yang menjadi asset kekayaan Baitul Mal itu sendiri.

Pemikiran ekonomi al-Mawardi tersebar paling tidak pada tiga buah karya tulisnya, yaitu Kitab Adab ad-Dunya wa ad-Din, al-Hawi dan al-Ahkam asSulthaniyyah. Dalam kitab Adab ad-Dunya wa ad-Din, ia memaparkan tentang perilaku ekonomi seorang muslim serta empat jenis mata pencaharian utama, yaitu pertanian, peternakan, perdagangan dan industri. Dalam kitab al-hawi, membahas tentang Mudharabah dalam pandangan berbagai mazhab. Dalam kitab al-Ahkam AsSulthaniyyah, ia banyak menguraikan tentang sistem pemerintahan dan administrasi 


\section{Tahkím}

Vol. XIV, No. 1, Juni 2018

agama Islam, seperti hak dan kewajiban penguasa terhadap rakyatnya, berbagai lembaga negara, penerimaan dan pengeluarn negara serta institusi hibah. ${ }^{13}$

\section{B. AL-GHAZALI}

\section{Pertukaran Sukarela dan Evolusi Pasar}

Pasar merupakan suatu tempat bertemunya antara penjual dengan pembeli. Proses timbulnya pasar yang berdasarkan kekuatan permintaan dan penawaran untuk menentukan harga dan laba. Tidak disangsikan lagi, al-Ghazali tampaknya membangun dasar-dasar dari apa yang kemudian dikenal sebagai "Semangat Kapitalisme". Bagi alGhazali, pasar berevolusi sebagai bagian dari 'hukum alam' segala sesuatu, yakni sebuah ekspresi berbagai hasrat yang timbul dari diri sendiri untuk saling memuaskan kebutuhan ekonomi. Al-Ghazali jelas-jelas menyatakan "mutualitas" dalam pertukaran ekonomi yang mengharuskan spesialisasi dan pembagian kerja menurut daerah dan sumber daya.

\section{Permintaan, Penawaran, Harga, dan Laba}

Sepanjang tulisannya, al-Ghazali berbicara mengenai "harga yang berlaku seperti yang ditentukan oleh praktek- praktek pasar", sebuah konsep yang dikemudian hari dikenal sebagai al-tsaman al-adil (harga yang adil) dikalangan ilmuan muslim atau equilibrium price (harga keseimbangan) dari kalangan Eropa kontemporer.

Beberapa paragraf dari tulisannya juga jelas menunjukkan bentuk kurva penawaran dan permintaan. Untuk kurva penawaran yang "naik dari kiri bawah ke kanan atas" dinyatakan oleh dia sebagai "jika petani tidak mendapatkan pembeli dan barangnya, ia akan menjualnya pada harga yang lebih murah". Sementara untuk kurva permintaan yang "turun dari kiri atas ke kanan bawah" dijelaskan oleh dia sebagai "harga dapat diturunkan dengan mengurangi permintaan."

\section{Etika Perilaku Pasar}

Dalam pandangan al-Ghazali, pasar harus berfungsi berdasarkan etika dan moral pelakunya. Secara khusus memperingatkan larangan mengambil keuntungan dengan cara menimbun makanan dan barang- barang lainnya, memberikan informasi yang salah mengenai berat, jumlah dan harga barangnya.

${ }^{13}$ M. Najatullah Siddiqi, Islamic Economic Thought: foundation, Evolution and Needed Direction, dalam Abdul Hasan M. Sideq dan Aidit Ghazali (ed.), Readings in Islamic Economic Thought (Selangor Darul Ehsan: Longman Malaysia, 1992), h. 18 


\section{Tahkím}

Vol. XIV, No. 1, Juni 2018

\section{Aktivitas Produksi}

Imam al-Ghazali mengklasifikasikan aktivitas produksi menurut kepentingan sosialnya serta menitikberatkan perlunya kerjasama dan koordinasi. Fokus utamanya adalah tentang jenis aktivitas yang sesuai dengan dasar- dasar etos Islam.

\section{a. Produksi Barang- barang Kebutuhan Dasar Sebagai Kewajiban Sosial}

Dalam hal ini, pada prinsipnya, negara harus bertanggung jawab dalam menjamin kebutuhan masyarakat terhadap barang-barang kebutuhan pokok. Disamping itu al- Ghazali beralasan bahwa ketidak seimbangan antara jumlah barang kebutuhan pokok yang tersedia dengan yang dibutuhkan masyarakat cenderung akan merusak kehidupan masyarakat.

\section{b. Hierarki Produksi}

Klasifikasi aktivitas produksi yang diberikan al-Ghazali hampir mirip dengan klasifikasi yang terdapat dalam pembahasan kontemporer, yakni primer (agrikultur), sekunder (manufaktur), dan tersier( jasa). Secara garis besar, ia membagi aktivitas produksi kedalam tiga kelompok berikut: (1) Industri dasar, yakni industri- industri yang menjaga kelangsungan hidup manusia (2) Aktivitas penyokong, yakni aktivitas yang bersifat tambahan bagi industri dasar (3) Aktivitas komplementer, yakni yang berkaitan dengan industri dasar.

\section{c. Tahapan Produksi, Spesialisasi, dan Keterkaitannya}

Al-Ghazali mengakui adanya tahapan produksi yang beragam sebelum produk dikonsumsi. Selanjutnya, ia menyadari kaitan yang sering kali terdapat dalam mata rantai produksi, sebuah gagasan yang sangat dikenal dalam pembahasan kontemporer. Tahapan dan keterkaitan produksi yang beragam mensyaratkan adanya pembagian kerja, koordinasi dan kerja sama. Ia juga menawarkan gagasan mengenai spesialisasi dan saling ketergantungan dalam keluarga.

\section{d. Barter dan Evolusi Uang}

Tampaknya al-Ghazali menyadari bahwa salah satu penemuan terpenting dalam perekonomian adalah uang. Ia menjelaskan bagaimana uang mengatasi permasalahan yang timbul dari pertukaran barter.

\section{1) Problem Barter dan Kebutuhan Terhadap Uang}

Al-Ghazali mempunyai wawasan yang sangat kompherhensif mengenai berbagai problema barter yang dalam istilah modren disebut sebagai: kurang memiliki angka penyebut yang sama (lack of common denominator), barang tidak dapat dibagibagi (indivisibility of goods) dan keharusan adanya dua keinginan yang sama (double coincidence of wants). Walaupun dapat dilakukan, pertukaran barter menjadi sangat 


\section{Tahkím}

Vol. XIV, No. 1, Juni 2018

tidak efisien karena adanya perbedaan karakteristik barang- barang (seperti unta dengan kunyit).

Fungsi uang menurut al-Ghazali adalah sebagai satuan hitung (unit of account), media penukaran (medim of exchange) dan sebagai penyimpan kekayaan (store of value). Adapun fungsi uang yang ketiga ini menurutnya adalah bukan fungsi uang yang sesungguhnya. Sebab, ia menganggap fungsi tersebut adalah sama saja dengan penimbunan harta yang nantinya akan berakibat pada pertambahan jumlah pengangguran dalam kegiatan ekonomi dan hal tersebut merupakan perbuatan zalim.

\section{2) Uang yang Tidak Bermanfaat dan Penimbunan Bertentangan Dengan Ilahi}

Dalam hal ini, al-Ghazali menekankan bahwa uang tidak diinginkan karena uang itu sendiri. Uang baru akan memiliki nilai jika digunakan dalam suatu pertukaran. Lebih jauh, ia menyatakan bahwa tujuan satu-satunya dari emas dan perak adalah untuk dipergunakan sebagai uang (dinar dan dirham). Ia mengutuk mereka yang menimbun kepingan- kepingan uang atau mengubahnya menjadi bentuk lain. ${ }^{14}$

Al-Ghazali menjelaskan bahwa orang yang melakukan penimbunan uang merupaka orang yang berbuat zalim dan menghilangkan hikmah yang terkandung dalam penciptaannya. Allah berfirman:

"dan orang-orang yang menyimpan emas dan perak dan tidak menafkahkannya pada jalan Allah, maka beritahukanlah kepada mereka (bahwa mereka akan mendapat) siksa yang pedih"15

\section{3) Pemalsuan dan Penurunan Nilai Uang}

Dalam hai ini ia membolehkan kemungkinan uang representatif (token money), seperti yang kita kenal dengan istilah modern- sebuah pemikiran yang mengantarkan kita pada apa yang disebut sebagai teori uang feodalistik yang menyatakan bahwa hak bendahara publik untuk mengubah muatan logam dalam mata uang merupakan monopoli penguasa feodal.

\section{4) Larangan Riba}

Al-Ghazali menyatakan bahwa menetapkan bunga atas utang piutang berarti membelokkan uang dari fungsi utamanya, yakni untuk mengukur kegunaan objek pertukaran. Oleh karena itu, bila jumlah uang yang diterima lebih banyak dari pada jumlah uang yang diberikan, akan terjadi perubahan standar nilai. Perubahan ini terlarang.

\footnotetext{
${ }^{14}$ Adiwarman A. Karim, op.cit., h. 336

${ }^{15}$ QS. at-Taubah ayat 24
} 


\section{Tahkím}

Vol. XIV, No. 1, Juni 2018

\section{Peranan Negara dan Keuangan Publik}

Dalam hal ini, ia tidak ragu- ragu menghukum penguasa. Ia menganggab negara sebagai lembaga yang penting, tidak hanya bagi berjalannya aktifitas ekonomi dari suatu masyarakat dengan baik, tetapi juga untuk memenuhi kewajiban sosial sebagaimana yang diatur oleh wahyu. Ia menyatakan, bahwa "negara dan agama adalah tiang-tiang yang tidak dapat dipisahkan darisebuah masyarakat yang teratur. Agama adalah fondasinya, dan penguasa yang mewakili negara adalah penyebar dan pelindungnya; bila salah satu dari tiang ini lemah, masyarakat akan ambruk."

\section{Kemajuan Ekonomi Melalui Keadilan, Kedamaian dan Stabilitas}

Al-Ghazali menitik beratkan bahwa untuk meningkatkan kemakmuran ekonomi, negara harus menegakkan keadilan, kedamaian dan keamanan, serta stabilitas. Ia menekankan perlunya keadilan serta " aturan yang adil dan seimbang." AlGhazali berpendapat negara bertanggung jawab dalam menciptakan kondisi yang layak untuk meningkatkan kemakmuran dan pembangunan ekonomi. Di samping itu, ia juga menulis panjang lebar mengenai lembaga al- Hisbah, sebuah badan pengawasan yang dipakai di banyak negara Islam pada waktu ini. Fungsi utama badan ini adalah untuk mengawasi praktik- raktik pasar yang merugikan.

Gambaran Al-Ghazali mengenai peranan khusus yang dimainkan oleh negara dan penguasa dituliskan dalam sebuah buku tersendiri yang berjudul Kitab Nasihat AlMuluk.

\section{Keuangan Publik}

Al-Ghazali memberikan penjelasan yang rinci mengenai peran dan fungsi keuangan publik. Ia memperhatikan kedua sisi anggaran, baik sisi pendapatan maupun sisi pengeluaran.

\section{a. Sumber-Sumber Pendapatan Negara}

Berkaitan dengan berbagai sumber pendapatan negara, al-Ghazali memulai dengan pembahasan mengenai pendapatan yang seharusnya dikumpulkan dari seluruh penduduk, baik muslim maupun non muslim, berdasarkan hukum Islam. Al- Ghazali menyebutkan bahwa salah satu sumber pendapatan yang halal adalah harta tanpa ahli waris pemiliknya, tidak dapat dilacak, ditambah sumbangan sedekahah atau wakaf yang tidak ada pengelolanya. Pajak-pajak yang dikumpulkan dari non muslim berupa Ghanimah, Fai, jaziyah dan upeti atau amwal al masalih. ${ }^{16}$ Disamping itu, al-Ghazali

\footnotetext{
${ }^{16}$ Ghanimah adalah pajak atas harta yang disita setelah atau selama perang. Fai adalah kepemilikan yang diperoleh tanpa melalui peperangan. Jaziyah dikumpulkan dari kaum non muslim sebagai imbalan dari dua keuntungan: pembebasan wajib militer dan perlindungan hak- hak sebagai penduduk.
} 


\section{Tahkím}

Vol. XIV, No. 1, Juni 2018

juga memberikan pemikiran tentang hal-hal lain yang berkaitan dengan permasalahan pajak seperti administrasi pajak dan pembagian beban diantara para pembayar pajak.

\section{b. Utang Publik}

Dengan melihat kondisi ekonomi, al-Ghazali mengizinkan utang publik jika memungkinkan untuk menjamin pembayaran kembali dari pendapatan dimasa yang akan datang. Contoh utang seperti ini adalah revenue bonds yang digunakan secara luas oleh pemerintah pusat dan lokal di Amerika Serikat. Menurut al-Ghazali, seseorang tidak dapat menyangkal izin bagi penguasa untuk meminjam dari rakyat ketika negara sangat membutuhkan. ${ }^{17}$

\section{c. Pengeluaran Publik}

Penggambaran fungsional dari pengeluaran publik yang direkomendasikan alGhazali bersifat agak luas dan longgar, yakni penegakan keadilan dan stabilitas negara, serta pengembangan suatu masyarakat yang makmur. Mengenai pembangunan masyarakat secara umum al-Ghazali menunjukkan perlunya membangun infrastruktur sosio ekonomi. Al-Ghazali mengakui "Konsumsi bersama" dan aspek spill-over dari barang-barang publik. Di lain tempat ia menyatakan bahwa pengeluaran publik dapat diadakan untuk fungsi-fungsi seperti pendidikan, hukum dan administrasi publik, pertahanan dan pelayanan kesehatan.

\section{Kajian Teori Pemikiran Ekonomi}

Ada kesamaan latar belakang keluarga antara al-Mawardi dan al-Ghazali yaitu berangkat dari keluarga sederhana. Begitu pula pandangan keduanya mengenai negara dan aktifitas ekonomi. Tetapi terdapat perbedaan yang mencolok dimana al-Mawardi dibesarkan di Baghdad pada masa kekuasaan Bani Buwaih penganut aliran Syi'ah sedang al-Ghazali tumbuh besar di Khurasan dimana terjadi pergeseran kekuasaan kepada Bani Saljuk adalah imperium Islam aliran Sunni. Al-Mawardi banyak mengangkat konsep Imamah, dimana dalam Syiah kepemimpinan itu mencakup persoalan keagamaan dan kemasyarakatan. ${ }^{18}$ sedang al-Ghazali mengangkat masalah ekonomi sufistik yang berdasarkan al-quran dan hadits dengan pemahaman para sahabat, tabi' in dan tabi tabi'in.

Di dunia barat ada dua tokoh utama aliran Scholistik, yaitu St. Albertus Magnus (1206-1280 M) dan St. Thomas Aquinas (1225-1274M). Albertus Magnus salah satu pandangannya yang terkenal adalah teori harga (just price) dimana harga yang adil dan pantas yaitu harga yang sama besarnya dengan biaya-biaya dan tenaga yang dikorbankan untuk menciptakan barang tersebut. Thomas Aquinas memvonis bunga sebagai riba dan menghukumi dosa pelakunya. Dilihat dari pemikiran dua tokoh

\footnotetext{
${ }^{17}$ Yadi Janwari, op.cit., h. 204.

${ }^{18}$ Azyumardi Azra, Dkk. Ensiklopedia Islam, (Jakarta: PT Ichtiar Baru Van Hoeve, 2005), h.
} 318. 


\section{Tahkím}

Vol. XIV, No. 1, Juni 2018

tersebut mendekati kesamaan dengan pandangan al-Ghazali tentang teori harga dan pendapatnya tentang pelarangan bunga atas piutang karena fungsi uang adalah alat tukar. Al-Ghazali hidup lebih awal dari kedua tokoh tersebut.

Jhon Maynard Keynes (1883-1946M) mengatakan mekanisme penyesuaian (adjustment) menjamin tercapainya keseimbangan perekonomian (equilibrium), ini sejalan dengan pemikiran al-Ghazali tentang tahapan produksi, spesialisasi, dan keterkaitannya, al-Ghazali banyak membahas teori ekonomi mikro makro, ia tampaknya membangun dasar-dasar dari apa yang kemudian dikenal sebagai "Semangat Kapitalisme." Bahkan Adam Smith (1729-1790M) dengan teori nilai (Value Theory) dan pembagian kerja (division of labor) terdapat korelasi dengan pemikiran Imam al-Ghazali.

Banyak literatur penelitian menyebutkan bahwa al-Ghazali adalah sosok yang diposisikan sebagai tokoh filosof, tasawuf, teolog, ahli fiqih dan tidak satupun yang mencatat bahwa beliau seorang ekonom. Bila kita telusuri catatan sejarah dan pemikiran dalam kajian ekonomi, maka kita akan menemukan kealpaan yang kadangkala telah merugikan kajian dan khazanah intelektual muslim. Jika kita telusuri beberapa pandangan dan pemikirannya dalam bidang ekonomi dapat digolongkan tokoh yang sangat brilian. Namun ide pemikirannya dalam ekonomi nyaris terlupakan sama sekali. Padahal jika diperhatikan secara seksama bahwa pemikiran al-Ghazali di bidang ekonomi akan memberikan kesan tidak kalah istimewanya dengan para tokoh ekonomi barat lainya.

\section{Kesimpulan}

Bertolak dari pembahasan yang telah dikemukakan di atas dapat disimpulkan bahwa pemikiran ekonomi al-Ghazali itulah, sangat banyak memberikan kontribusi terhadap perkembangan pemikiran ekonomi sesudahnya. Pengaruhnya tidak hanya pada dunia muslim tetapi juga non muslim. Hal ini sangat dirasakan oleh beberapa ekonom muslim kontemporer yang selalu menyebut visi dan prinsip ekonominya yang selalu mengutip dari pemikiran ekonomi al-Ghazali dijadikan pijakan dan landasan utama untuk meletakkan visi ekonomi Islam yang berkembang saat ini.

\section{DAFTAR PUSTAKA}

Azra, Azyumardi, dkk. Ensiklopedia Islam, Jakarta: PT Ichtiar Baru Van Hoeve, 2005. Amalia, Euis. Sejarah Pemikiran Ekonomi Islam, Jakarta: Gramata Publishing, 2005. Al-Ghazali, Abu Hamid. Ihya 'Ulum al-Din, Beirut: Dar al-Nadwah, t.th. Janwari, Yadi. Pemikiran Ekonomi Islam, Bandung: PT Remaja Rosdakarya, 2016.

Karim, Adiwarman A. Ekonomi Islam Suatu Kajian Kontemporer, Jakarta: Gema Insani Press, 2004. 


\section{Tahbím}

Vol. XIV, No. 1, Juni 2018

------. Sejarah Pemikiran Ekonomi Islam, Jakarta: Raja Grafindo Persada, 2006.

Munir, Misbahul. Ajaran-Ajaran Ekonomi Rasulullah Kajian Hadits Nabi dalam Perspektif Ekonomi, Jakarta: UIN-Press, 2007.

Siddiqi, M. Najatullah. Islamic Economic Thought: foundation, Evolution and Needed Direction, dalam Abdul Hasan M. Sideq dan Aidit Ghazali (ed.), Readings in Islamic Economic Thought, Selangor Darul Ehsan: Longman Malaysia, 1992.

ToddLowry, The Archeology of Economic Ideas: The Classied Greek Tradition, Durham: Duke University Press, 1987 